\title{
Partial genome sequence of a Potyvirus and of a virus in the order Tymovirales found in Senna macranthera in Brazil
}

\author{
José Evando A. Beserra Jr.", Murilo G. de Carvalho, Beatriz M. Barguil ${ }^{*}$ \& F. Murilo Zerbini \\ Departamento de Fitopatologia/BIOAGRO, Universidade Federal de Viçosa, Viçosa, MG, 36570-000, Brazil
}

Author for correspondence: F. Murilo Zerbini, e-mail: zerbini@ufv.br

\begin{abstract}
Senna macranthera is a common tropical tree native to South- and Northeastern Brazil. In July 2006, symptoms of chlorotic spots in the young leaves and mild mosaic in the old leaves were observed in S. macranthera trees at Viçosa, State of Minas Gerais, Brazil. Electron microscopy examination of leaf dip preparations from the young leaves revealed the presence of flexuous rods. Viral RNA was extracted from purified virion preparations and used as a template for the RT-PCR-based cloning of viral genomic fragments. Two fragments $(0.9 \mathrm{~kb}$ and $2.0 \mathrm{~kb}$ in length) were cloned. Sequence analysis of the $0.9 \mathrm{~kb}$ fragment indicated that it corresponded to the NIb coding region of a potyvirus, with nucleotide (nt) identity level of $72 \%$ for Pepper mottle virus (PepMoV) and Peru tomato mosaic virus (PTV), while analysis of the $2.0 \mathrm{~kb}$ fragment indicated that it corresponded to the putative replicase ORF, which displayed $74 \% \mathrm{nt}$ identity with the ORF1 (replicase) of Garlic virus A (GarV-A). Based on molecular analysis and the isolates' host range, it is concluded that the viral fragments represent new viruses, for which we propose the names Senna virus Y (genus Potyvirus, family Potyviridae) and Senna virus X (unassigned genus, order Tymovirales).
\end{abstract}

Key words: Senna virus X, Senna virus Y, molecular characterization.

\section{RESUMO}

Sequências genômicas parciais de um Potyvírus e um vírus da ordem Tymovirales encontrados em Senna macranthera no Brasil Senna macranthera é uma árvore tropical nativa do Sudeste e Nordeste brasileiro. Em julho de 2006, sintomas de manchas cloróticas nas folhas jovens e de mosaico leve nas folhas mais velhas foram observados em plantas de $S$. macranthera em Viçosa, Estado de Minas Gerais, Brasil. A observação de preparações "leaf-dip" em microscópio eletrônico de transmissão revelou a presença de partículas alongado-flexuosas. O RNA viral foi extraído de vírions purificados e utilizado como molde para RT-PCR e clonagem de fragmentos do genoma viral. Dois fragmentos ( $0,9 \mathrm{~kb}$ e $2,0 \mathrm{~kb}$ de tamanho) foram clonados. A análise da sequência do fragmento de $0,9 \mathrm{~kb}$ indicou que este corresponde à região codificadora da proteína NIb de um potyvírus, com $72 \%$ de identidade de nucleotídeos com o Pepper mottle virus (PepMoV) e Peru tomato mosaic virus (PTV), enquanto a análise do fragmento de $2,0 \mathrm{~kb}$ indicou que este corresponde à ORF que codifica a possível replicase de um vírus classificado na recém-estabelecida ordem Tymovirales, com 74\% de identidade de nucleotídeos com o Garlic virus A (GarV-A). Com base na análise molecular e na gama de hospedeiros, conclui-se que os fragmentos virais clonados representam novas espécies, para as quais sugerem-se os nomes Senna virus Y (gênero Potyvirus, família Potyviridae) e Senna virus X (ordem Tymovirales, gênero não definido).

Palavras-chave: Senna virus X, Senna virus Y, caracterização molecular.

Senna macranthera (Collad.) H.S. Irwin \& Barnedy (syn. Cassia macranthera Collad.), known as "manduirana" or "fedegoso", is a common tropical tree in South- and Northeastern Brazil. This leguminous plant, with dense foliage and abundant yellow flowers, is a native plant commonly used for urban landscaping and also in the reforestation of degraded mining areas (Lorenzi, 1992). In Brazil, three viruses have been found infecting Senna species. A strain of Soybean mosaic virus was reported on

*Present address: Universidade Estadual do Piauí, Picos, PI, 64600000, Brazil. E-mail: evandojr@yahoo.com

The sequences reported in this paper have been deposited in the GenBank under the accession numbers GU481094 and GU481095.
Senna occidentalis, and the coat protein (CP) gene of this virus was cloned and sequenced (Almeida et al., 2002). Two other viruses were found infecting Senna species in Brazil in the 1970's and 1980's (Lin et al., 1979; Paguio \& Kitajima, 1981). They were tentatively identified as a potyvirus and a carlavirus based on particle morphology and biological and serological properties. However, there is no information on their nucleotide sequences. Herein, we report on the molecular identification and host range of a new potyvirus, and the detection of a putative novel virus, classified in the recently established order Tymovirales, found in $S$. macranthera. Their partial genome sequences indicate that neither of the two viruses has been sequenced before.

In July 2006, symptoms of chlorotic spots in the young leaves (Figure 1A) and mild mosaic in the old 

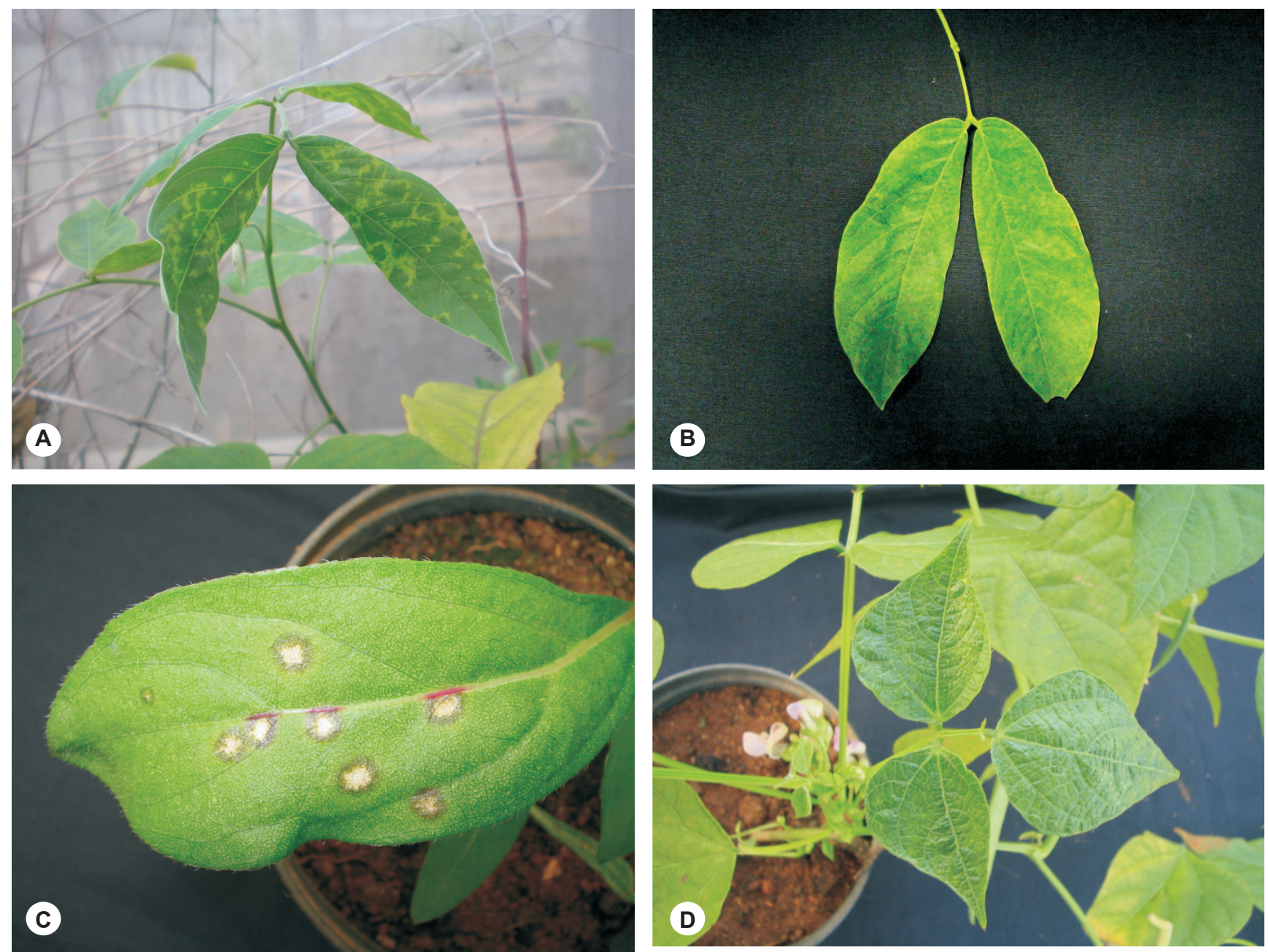

FIGURE 1 - A. Chlorotic ringspots in the young leaves of a Senna macranthera plant, collected at Viçosa, State of Minas Gerais, Brazil, and later shown to be doubly infected by a potyvirus and a virus classified in the order Tymovirales; B. Mosaic in $S$. macranthera after back-inoculation with tissue from necrotic local lesions from Gomphrena globosa; C. Necrotic local lesions in Gomphrena globosa; D. Mild mosaic in Phaseolus vulgaris cv. Pérola.

leaves were observed in S. macranthera trees located at Viçosa, Minas State of Gerais, Brazil. About $40 \%$ of the observed plants in the area had the described symptoms and those plants were also considerably less leafy than the surrounding healthy-looking trees. The young leaves exhibiting chlorotic spots were collected, and electron microscopic examination of leaf dip preparations from these leaves revealed the presence of flexuous rods typical of potyviruses. Sap prepared from the leaves was mechanically inoculated into plants commonly used as virus indicators. The biological assay was conducted with plants of nine families, totaling 26 species and cultivars: Cucurbita pepo L., Lactuca sativa L. cv. Elisa, Amaranthus hybridus L., Chenopodium amaranticolor (Coste \& A. Reyn.), C. quinoa Willd., Datura stramonium L., Phaseolus vulgaris L. cvs. Manteigão, Ouro Negro and Pérola, Gomphrena globosa L., Carica papaya L., Passiflora edulis Sims f. flavicarpa, Citrullus lanatus (Thunb.) Matsum. \& Nakai,
Nicotiana benthamiana Domin., N. clevelandii A. Gray, $N$. debneyi, $N$. glutinosa L., $N$. tabacum L. cvs. Havana, TNN and White Burley, Nicandra physaloides (L.) Gaertn., Physalis floridana (Rydb), Capsicum annuum L., Solanum lycorpesicum L., Vigna radiata L. cv. Mungo Verde, V. unguiculata (L.) Walp and Senna macranthera. Five plants of each species or cultivar were inoculated using $0.02 \mathrm{M}$ phosphate buffer, $\mathrm{pH} 7.2$, plus $0.1 \%$ sodium sulfite, and one plant was inoculated with buffer only. The plants were observed until 30 days after inoculation. Sap from plants which remained symptomless after this period was used to back-inoculate plants of $S$. macranthera, in order to check for the occurrence of latent infections.

The virus was purified from $S$. macranthera plants by extraction with $0.5 \mathrm{M}$ phosphate buffer, $\mathrm{pH} 7.2$, with $0.01 \mathrm{M}$ EDTA and $0.1 \%$ sodium sulfite, clarification with $8 \%$ n-butanol, precipitation with $8 \%$ PEG 6000 , and two cycles of differential centrifugation, as described by Souto 
\& Kitajima (1992). Spectrophotometric analysis of the purified preparation revealed a UV spectrum typical of nucleoproteins with a $260 \mathrm{~nm}$ peak. Viral RNA was extracted from $50 \mu \mathrm{L}$ of viral concentrate according to Krause-Sakate et al. (2001) and resuspended in $20 \mu \mathrm{L}$ of DEPC-treated, sterile water. First-strand cDNA was synthesized using Superscript III Reverse Transcriptase (Invitrogen) and oligo(dT) ${ }_{14}$ as a primer. PCR-based amplification of a viral genomic fragment was carried out using High Fidelity Taq DNA polymerase (Invitrogen) and a degenerate potyvirus primer (Poty4, Zerbini et al., 1995) in combination with oligo(dT $)_{14}$. PCR amplification was performed with an initial denaturing step at $94^{\circ} \mathrm{C}$ for 2 min followed by 30 cycles of denaturation $\left(94^{\circ} \mathrm{C} / 1 \mathrm{~min}\right)$, annealing $\left(53^{\circ} \mathrm{C} / 1\right.$ $\min$ ) and extension $\left(68^{\circ} \mathrm{C} / 2 \mathrm{~min}\right)$, with a final extension at $68^{\circ} \mathrm{C}$ for $5 \mathrm{~min}$. The amplified products were visualized in a $1 \%$ agarose gel stained with ethidium bromide under UV light.

DNA fragments of approximately $2.0 \mathrm{~kb}$ and 0.9 $\mathrm{kb}$ in size were amplified, purified from agarose gels (Illustra Gel Band; Gel Band Purification, GE Healthcare) and cloned into the pGEM-T-Easy vector (Promega). Five clones each of the $2.0 \mathrm{~kb}$ and $0.9 \mathrm{~kb}$ amplicons, sequenced on both strands, were used to obtain the consensus nucleotide sequences for the isolates. The fragments were sequenced at Macrogen, Inc. (Seoul, South Korea). The $2.0 \mathrm{~kb}$ fragments were sequenced by primer walking. The nucleotide (nt) and deduced amino acid (aa) sequences were initially submitted to a BLAST (www.ncbi.nlm.nih. gov/blast) search for preliminary species assignment. Additional nt and aa pairwise comparisons were made with DNAMan version 4.0 (Lynnon Biosoft). Neighbor-joining trees were generated using MEGA 4.0 (Tamura et al., 2007) with 2000 bootstrap replications.

Among the assessed plants, only C. amaranticolor, $P$. vulgaris cv. Pérola, G. globosa, V. radiata cv. Mungo Verde and $S$. macranthera exhibited symptoms when inoculated with sap from leaves of symptomatic $S$. macranthera. $G$. globosa exhibited necrotic local lesions three days after inoculation (Figure 1C). C. amaranticolor displayed chlorotic local lesions, while $P$. vulgaris cv. Pérola and $V$. radiata $\mathrm{cv}$. Mungo Verde displayed a mild mosaic (Figure 1D). S. macranthera exhibited chlorotic ring spots (Figure 1A). None of the asymptomatic plants induced symptoms when back-inoculated onto $S$. macranthera. Also, $S$. macranthera plants were back-inoculated with tissue from necrotic local lesions from G. globosa, in an attempt to isolate the virus, which resulted in mild mosaic symptoms (Figure 1B).

According to Lin et al. (1979) and Lin et al. (1980), necrotic local lesions in $G$. globosa were observed after inoculation of a possible carlavirus from S. sylvestris (Vell.) H.S. Irwin \& Barneby and S. macranthera. The authors concluded, by examining 54 plant species in 13 botanical families, that the virus (tentatively named Cassia mild mosaic virus), was able to infect only plants of Senna spp. and cause necrotic local lesions in G. globosa. In other studies, mosaic symptoms and local chlorotic lesions were observed in leguminous plants (bean, cowpea and soybean) and $C$. amaranticolor, respectively, after inoculation of a potyvirus found in Senna hoffmannseggii Mart. (Paguio \& Kitajima, 1981; Souto \& Kitajima, 1991). Therefore, the results of our biological assay suggest that the $S$. macranthera plants could be doubly infected by a potyvirus and a possible carlavirus.

The two fragments amplified by the RT-PCR assay were cloned and sequenced. The sequence of the $0.9 \mathrm{~kb}$ fragment showed a higher identity to a potyviral genome. The single 5'-truncated open reading frame has 933 nucleotides and spans about two thirds of the NIb gene (the last 311 amino acids). All expected consensus aa sequences are present, including the GDD triplet present in all RNAdependent RNA polymerases (RdRp) of (+) ssRNA viruses and the YEVRHQ sequence at the NIb/CP cleavage site. Database searches using nt and aa sequences revealed a close relationship with Pepper mottle virus (PepMoV) and Peru tomato mosaic virus (PTV), with identity levels of $72 \%$ nt and $83 \%$ aa for PepMoV, and of $72 \%$ nt and $80 \%$ aa for PTV. Phylogenetic analysis based on nt sequences showed that this virus groups together with potyviruses that infect solanaceous hosts (potato and pepper) with 100\% bootstrap confidence (Figure 2A).

Given the species demarcation criteria for the family Potyviridae of $76 \% \mathrm{nt}$ and $89 \%$ aa sequence identity for the NIb gene (Adams et al., 2005b), the maximum values obtained herein for the partial sequence of the $S$. macranthera virus (72\% nt and $83 \%$ aa) indicate that this viral isolate could represent a new potyvirus species. In 1981, a virus with biological and cytopathological properties of a potyvirus was found infecting $S$. hoffmannseggii in Northeastern Brazil (Paguio \& Kitajima, 1981; Souto \& Kitajima, 1991). The authors proposed the tentative name Cassia yellow spot virus (CYSV). Recently, a virus with the same characteristics infecting $S$. hoffmannseggii has been identified as an isolate of Cowpea aphid borne mosaic virus (CABMV) (G. Pio-Ribeiro, personal communication). Although the potyvirus found in S. macranthera has a host range similar to that of CYSV/CABMV (inducing chlorotic local lesions in $C$. amaranticolor, and mild mosaic in $P$. vulgaris and $V$. radiata), it is clearly distinct from CABMV based on the molecular analysis. Therefore, we conclude that it is indeed a new virus, for which we propose the name Senna virus Y (SVY).

Surprisingly, the sequence analysis of the $2.0 \mathrm{~kb}$ fragment indicated a close relationship with viruses in the newly established order Tymovirales (www.ictvonline.org). The fragment corresponds to part of the ORF encoding an RNA dependent RNA polymerase (RdRp), based on the presence of NTPase, RNA helicase and RdRp domains. The $n t$ and aa sequences displayed $67 \%$ and $74 \%$ identity, respectively, with the partial ORF1 of Garlic virus A (GarVA), $67 \%$ and $72 \%$ with Garlic virus C (GarV-C) and $67 \%$ 

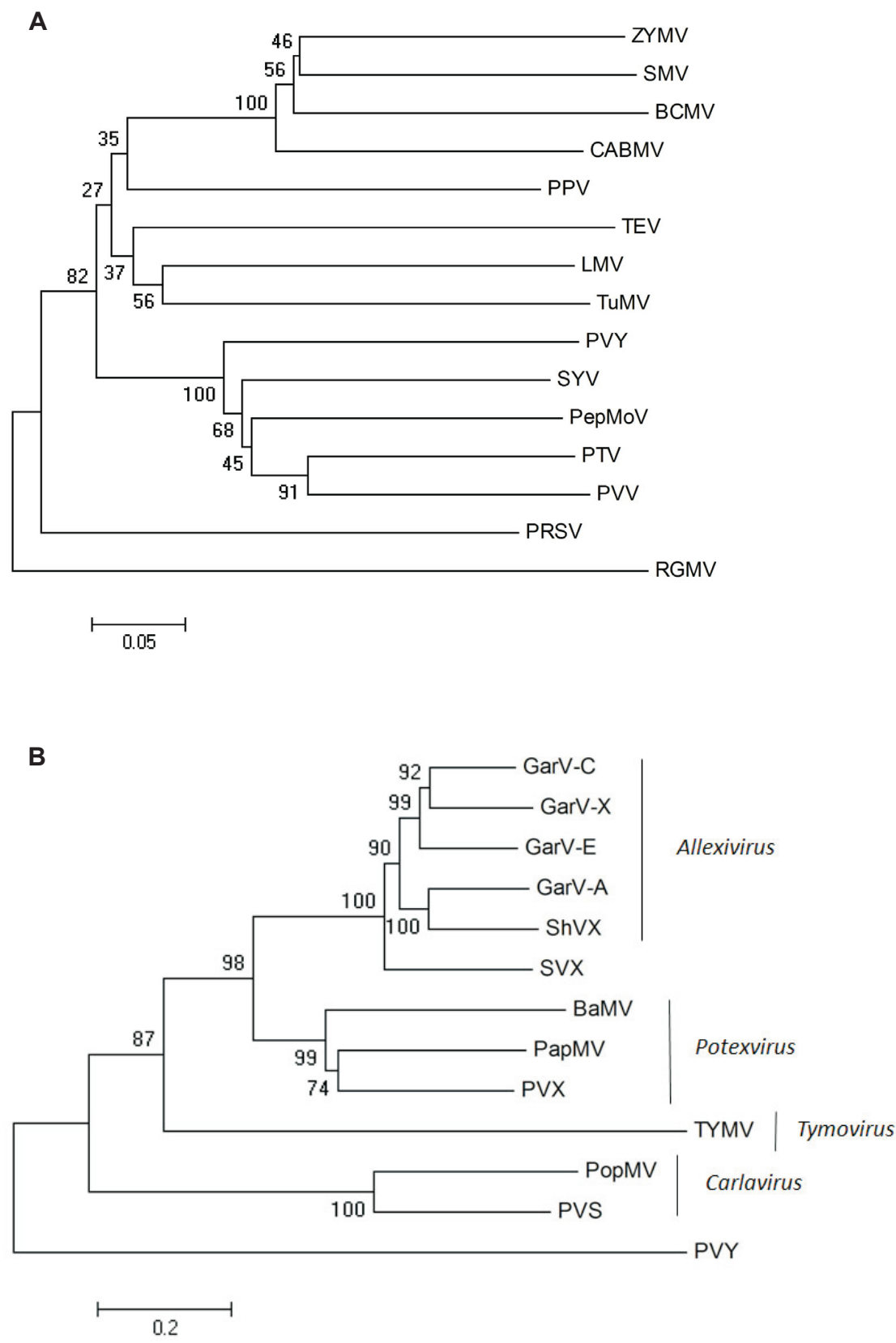

FIGURE 2 - A. Phylogenetic tree based on the nucleotide sequences of the NIb coding region of the potyvirus (SVY, Senna virus Y - virus under study) detected in Senna macranthera and additional sequences of related potyviruses. Horizontal distances are proportional to the genetic distances among the isolates. Vertical distances are arbitrary. The numbers on each branch represent bootstrap values (2000 replications). BCMV, Bean common mosaic virus (GenBank access number AJ312437); CABMV, Cowpea aphid-borne mosaic virus (AF348210); LMV, Lettuce mosaic virus (X97704); PepMoV, Pepper mottle virus (AB126033); PPV, Plum pox virus (X16415); PRSV, Papaya ringspot virus (AY010722); PTV, Peru tomato mosaic virus (AJ437280); PVV, Potato virus V (AJ243766); PVY, Potato virus Y (FJ214726); SMV, Soybean mosaic virus (D00507); SVY, Senna virus Y (GU481095); TEV, Tobacco etch virus (M15239); TuMV, Turnip mosaic virus (AF169561); ZYMV, Zucchini yellow mosaic virus (AJ307036). Outgroup: RGMV, Ryegrass mosaic virus (AF035818), gen. Rymovirus, fam. Potyviridae. B. Phylogenetic tree based on the nucleotide sequence of the putative replicase gene of the virus (SVX, Senna virus X-virus under study) detected in Senna macranthera and additional sequences of the ORF1 (RdRp) of viruses classified in the order Tymovirales. Horizontal distances are proportional to the genetic distances among the isolates. Vertical distances are arbitrary. The numbers on each branch represent bootstrap values (2000 replications). Genus Potexvirus, fam. Alphaflexiviridae: BaMV, Bamboo mosaic virus (AF018156); PapMV, Papaya mosaic virus (D13957); PVX, Potato virus X (M95516). Genus Allexivirus, fam. Alphaflexiviridae: GarV-A, Garlic virus A (AB010300); GarV-C, Garlic virus C (AB010302); GarV-E, Garlic virus E (AJ292230); GarV-X, Garlic virus X (AJ292229); SVX, Senna virus X (GU481094); ShVX, Shallot virus X (M97264). Genus Carlavirus, fam. Betaflexiviridae: PopMV, Poplar mosaic virus (AY505475); PVS, Potato virus S (AJ863509). Genus Tymovirus, fam. Tymoviridae: TYMV, Turnip yellow mosaic virus (X07441). Outgroup: PVY, Potato virus Y (X12456), gen. Potyvirus, fam. Potyviridae. 
and $73 \%$ with Garlic virus E (GarV-E), all species classified in the genus Allexivirus (family Alphaflexiviridae, order Tymovirales). Phylogenetic analysis based on nt sequences showed that this virus groups together with allexiviruses that infect garlic with $100 \%$ bootstrap confidence (Figure 2B).

A virus named Cassia mild mosaic virus (CasMMV) was previously described infecting $S$. sylvestris and $S$. macranthera (Lin et al., 1979, 1980). CasMMV was tentatively identified as a carlavirus based on biological and cytopathological properties. The reported host range of CasMMV is similar to that observed for the virus represented by $2.0 \mathrm{~kb}$ clone (systemic infection restricted to Senna species, necrotic local lesions in G. globosa; Lin et al., 1979). However, sequence and phylogenetic analysis argue against them being isolates of the same species, since identities between the $2.0 \mathrm{~kb}$ fragment and species in the genus Carlavirus are very low, and carlaviruses were placed distantly in the phylogenetic tree (Figure 2B). Although it is possible that CasMMV was not really a carlavirus, but an allexivirus, and despite the phylogenetic analysis indicating that the virus represented by the $2.0 \mathrm{~kb}$ clone clusters with species of the genus Allexivirus (Figure 2B), it is premature to suggest that it could be a member of this genus, or even of the family Alphaflexiviridae, since the analysis of a partial sequence of the $\mathrm{RdRp}$, a notoriously conserved protein, can lead to a mistaken identity. Therefore, this virus can only be safely classified as unassigned species belonging to the order Tymovirales, for which we propose the name Senna virus X (SVX). Further assignment at the family or genus levels will require additional sequencing.

Particles of many viruses in the Tymovirales are flexuous rods approximately $800 \mathrm{~nm}$ in length, thus resembling potyviruses in their morphology (Adams et al., 2005a). It is therefore not surprising that the initial electron microscopic analysis of the symptomatic leaves of the $S$. macranthera plant did not distinguish the presence of the two viruses. However, the amplification of a genomic fragment from a virus from the order Tymovirales using a potyvirus-specific primer was unexpected, and could be explained by the high degree of degeneracy (512-fold) in the Poty4 primer (Zerbini et al., 1995), allowing for imperfect base pairing at the temperature used for the PCR reaction. In any event, we have detected for the first time two viruses naturally infecting $S$. macranthera: a new potyvirus and a new virus classified in the order Tymovirales, possibly an allexivirus. The role of Senna spp. as a reservoir of taxonomically diverse plant viruses should be investigated in greater detail.

\section{REFERENCES}

Adams MJ, Accotto G, Agranovsky AA, Bar-Joseph M, Boscia D, Brunt AA, Candresse T, Coutts RHA, Dolja VV, Falk BW, Foster GD, Gonsalves D, Jelkmann W, Karasev AV, Martelli GP, Mawassi M, Milne RG, Minafra A, Namba S, Rowhani A, Vetten HJ, Vishnichenko VK, Wisler GC, Yoshikawa N, Zaravriev SK. (2005a) Family Flexiviridae. In: Fauquet CM, Mayo MA, Maniloff J, Desselberger U, Ball LA (Eds.) Virus Taxonomy. Eighth Report of the International Committee on Taxonomy of Viruses. San Diego CA. Elsevier Academic Press. pp. 1089-1124.

Adams MJ, Antoniw JF, Fauquet CM (2005b) Molecular criteria for genus and species discrimination within the family Potyviridae. Archives of Virology 150:459-479.

Almeida AMR, Sakai J, Souto ER, Kitajima EW, Fukuji T, Hanada K (2002) Mosaic in Senna occidentalis in southern Brazil induced by a new strain of Soybean mosaic virus. Fitopatologia Brasileira 27:151-156.

Krause-Sakate R, Mello RN, Zambolim EM, Pavan MA, Carvalho MG, Le Gall O, Zerbini FM (2001) Molecular characterization of two Brazilian isolates of Lettuce mosaic virus (LMV) with distinct biological properties. Fitopatologia Brasileira 26:153-157.

Lin MT, Kitajima EW, Cupertino FP, Costa CL (1979) Properties of a possible carlavirus isolated from a Cerrado native plant, Cassia sylvestris. Plant Disease Reporter 63:501-505.

Lin MT, Kitajima EW, Costa CL (1980) Association of Cassia mild mosaic virus with dieback of Cassia macranthera in central Brazil. Plant Disease 64:587-589.

Lorenzi H (1992) Árvores brasileiras: Manual de identificação e cultivo de plantas arbóreas nativas do Brasil. Nova Odessa. Editora Plantarum.

Paguio OR, Kitajima EW (1981) Isolamento de um potyvírus de Cassia hoffmannsegii Mart. Fitopatologia Brasileira 6:187-191.

Souto ER, Kitajima EW (1991) Propriedades biológicas de um potyvírus isolado de "Lava Pratos" (Cassia hoffmannseggii) procedente de Pernambuco. Fitopatologia Brasileira 16:256-259.

Souto ER, Kitajima EW (1992) Purificação do vírus das manchas amarelas da Cassia, eletroforese de proteína e sorologia. Fitopatologia Brasileira 17:292-301.

Tamura K, Dudley J, Nei M, Kumar S (2007) MEGA4: Molecular Evolutionary Genetics Analysis (MEGA) software version 4.0. Molecular Biology and Evolution 24:1596-1599.

Zerbini FM, Koike ST, Gilbertson RL (1995) Biological and molecular characterization of lettuce mosaic potyvirus isolates from the Salinas Valley of California. Phytopathology 85:746752 .

TPP 180 - Received 23 September 2010 - Accepted 5 April 2011 Section Editor: Alice K. Inoue Nagata 